\title{
SCIENTIFIC REPORTS

\section{Sustainable use zoning of land resources considering ecological and geological problems in Pearl River Delta Economic Zone, China}

\begin{abstract}
Lin $\mathrm{Gao}^{1}$, Chuanming $\mathrm{Ma}^{2 *}$, Oixin Wang ${ }^{3}$ \& Aiguo Zhou ${ }^{4}$
The Pearl River Delta Economic Zone is one of the fastest growing areas of China's social and economic development. However, the contradiction between people and land, the deterioration of ecological environment and the damage of urban ecological security have become more serious problems. In previous studies there was single land utilization type in small-area and the evaluation method was not suitable to large areas, this study proposes a new method. Firstly, the study implements ecological land zoning from assessing the importance of ecosystem services functional in four aspects: biodiversity, water conservation, soil conservation and coastal protected zone. Then, the suitability evaluation index system of agricultural and construction land is established from the geological environment perspective, and introduces variable weight-analytical hierarchy process-comprehensive index model to evaluate the suitability of agricultural land and construction land. Re-zoning the type of land that has a special effect on the socio-economic, the mining land, protected area of geological relics and groundwater resources, respectively. Finally, considering the actual condition use status and suitability distribution of land, the results of comprehensive zoning of land utilization is got. The results of this study can provide some geological basis for the future land utilization zoning.
\end{abstract}

With the rapid development of China's economy and urbanization process, the land utilization types have changed dramatically of Pearl River Delta Economic Zone ${ }^{1}$. Due to the land utilization structure and layout are not rational, construction land occupies large-scale agricultural land, leading to a sharp decline in agricultural land and ecological degradation of land resource ${ }^{2,3}$, which has heavily exploited natural resources and damaged geological environment conditions. This has led to a series of geological environmental problems, such as groundwater pollution, soil heavy metal pollution, soil erosion, ecosystem degradation, and loss of biodiversity ${ }^{4,5}$. Targeting these problems, some researchers have proposed to re-zoning the land utilization types of cities in the Pearl River Delta Economic $Z_{\text {Zne }}{ }^{6,7}$. But previous studies concentrated in a certain city or a small area, lacked the research on land utilization in the area of space $^{3,8,9}$. With the continuous innovation of land utilization zoning research methods, land utilization zoning research presents a new trend of modernization, stratification and integration ${ }^{10-15}$. Researchers began using GIS platform, zoning by different methods ${ }^{11,12,16}$ based on measurement data and weighting criteria, apply multi-factor models with the help of IDRISI GIS software, researched the applicability of commercial agriculture, small-scale agriculture, urban development, nature conservation, respectively. Ceballos-Silva, A. ${ }^{17}$ used the pairwise comparison method to determine the weight, and used the $0-5$ scale to evaluate the results, then conducted the land suitability evaluation of particular crop; Giap, D.H. ${ }^{18}$ used Analytic Hierarchy Process (AHP), under taking into account constraints, used the relative importance of specific factors to measure and assess applicability; Liu, Y. ${ }^{19}$ developed an adaptive fuzzy inference method for evaluation of agricultural land in Hubei Province. However, the area of above study is small, and most of the research zoning methods are directed to a single land type, which does not meet the requirements of overall zoning. Oliver T. Hogg ${ }^{20}$ proposing to analyze state of marine protected area through landscape mapping data in southern Antarctica. Soumendra N. Bhanja ${ }^{21}$ achieved the effectiveness of India's water management policy by tracking data on groundwater in parts of India. In the few zonings of virous land types, the functional applicability of virous land types was neglected, and a single evaluation method was used to

${ }^{1}$ School of Geological Survey, China University of Geosciences, Wuhan, China. ${ }^{2}$ School of Environmental Studies, China University of Geosciences, Wuhan, China. ${ }^{3}$ China Railway Design Corporation, Tianjin, 300251, China. ${ }^{4}$ School of Environmental Studies, China University of Geosciences, Wuhan, 430074, China. *email: machuanming@cug.edu.cn 


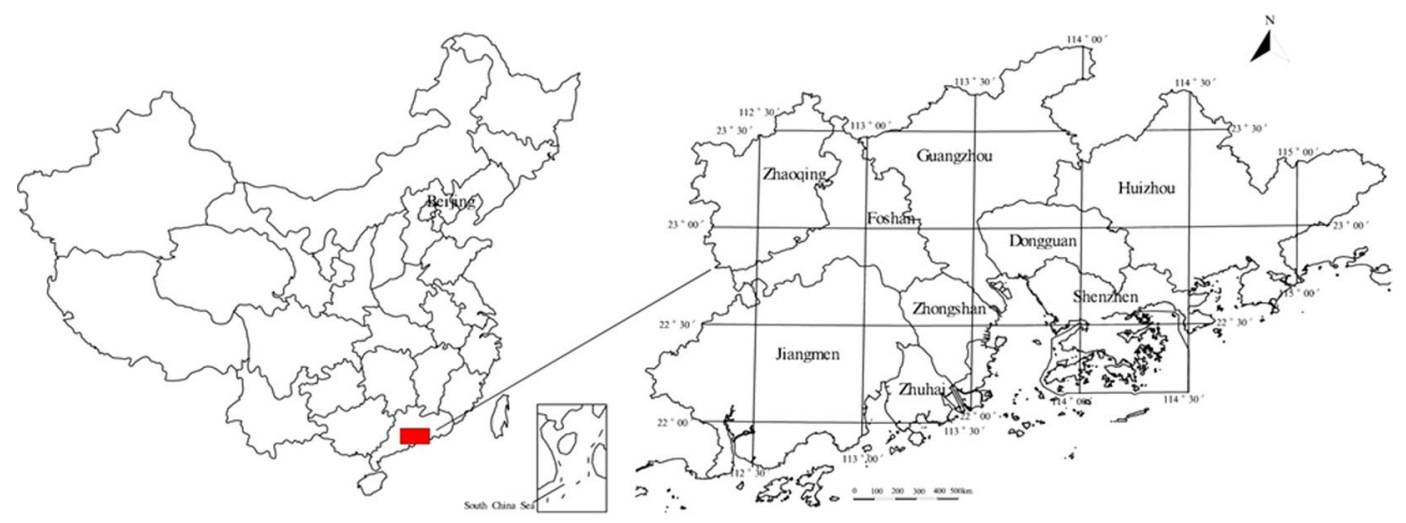

Figure 1. The Location and Scope of the study area.

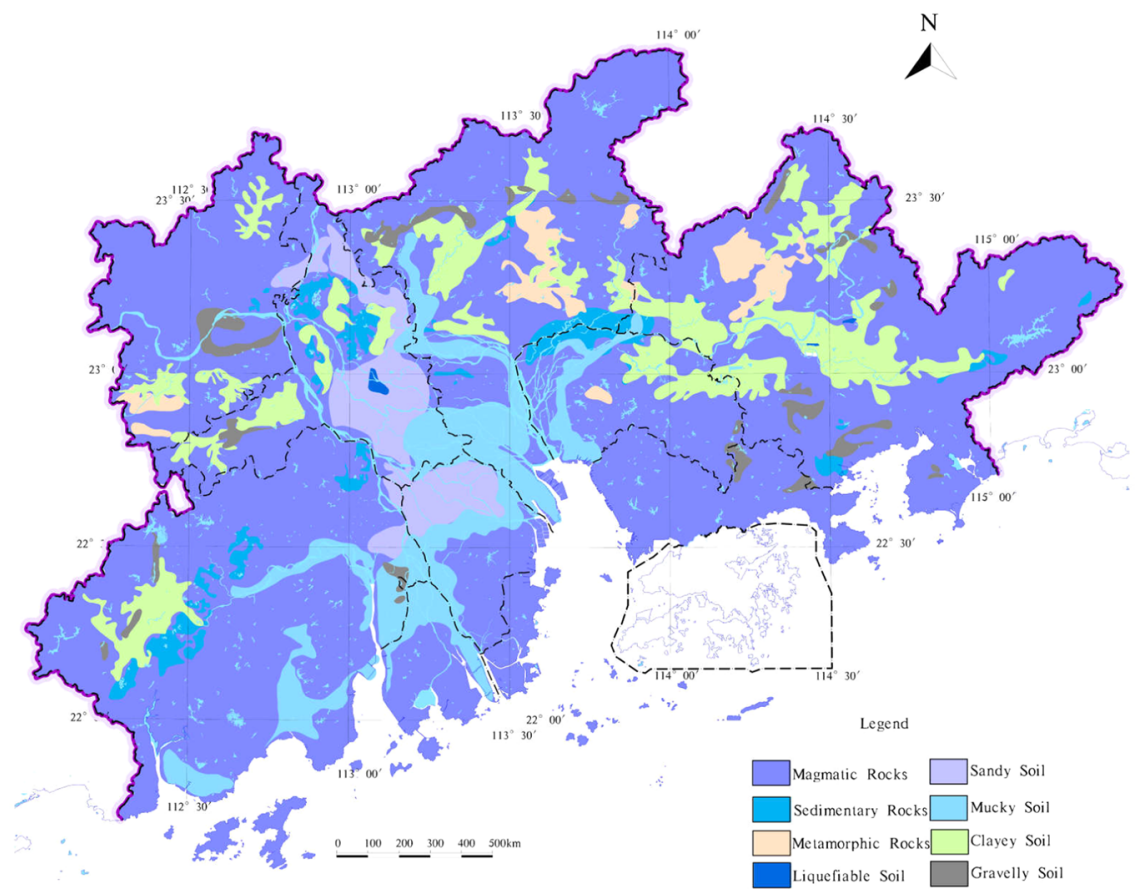

Figure 2. The engineering geology of the study area.

virous land types zoning $22-24$. And more attention was paid to the developmental forces of human social and economy, missing from the perspective of basic geological environment conditions consider the land utilization types, resulting in conflicting land resource, further deterioration of the ecological environment ${ }^{25,26}$. Therefore, this paper takes the Pearl River Delta Economic Zone as an example, based on the premise of ensuring regional ecological and environmental security, evaluation the ecological land by objective weighting method. Starting from the geological environment elements associated with land utilization types, in order to solve the problem that the weight of the evaluation factors constant in the evaluation process, the partial decision results are greatly deviated, the evaluation of agricultural land and construction land by variable weight- analysis hierarchy process-comprehensive index met $\operatorname{hod}(\text { VWAHP-CIM) })^{11,13,16,18,27,28}$.

\section{Study Area}

The study area - the Pearl River Delta Economic Zone is located east longitude $111^{\circ} 59^{\prime} 42^{\prime \prime}-115^{\circ} 25^{\prime} 18^{\prime \prime}$ and latitude $21^{\circ} 17^{\prime} 36^{\prime \prime}-23^{\circ} 55^{\prime} 54^{\prime \prime}$, with a total area of about $55407 \mathrm{~km}^{2}$, including 9 administrative regions (Fig. 1). In the study area, the terrain is flat and the topography is small. From the oldest Mesoproterozoic metamorphic rocks to the latest Quaternary loose debris deposition have exposed. Most of the study area are covered by Quaternary and magmatic rocks are widely exposed to the surface, which account for about $30 \%$ of the study area. In the river network area and the coastal plain area, the surface is covered with silt clay, which has the characteristics of low shear strength, high compressibility and low bearing capacity (Fig. 2). Local presence seawater intrusion in the study area, which forms different degrees of salt water ${ }^{7,29}$. There are geological hazards and environmental problems such as collapse, debris flow, land subsidence, groundwater pollution and soil heavy metal pollution ${ }^{30,31}$. 


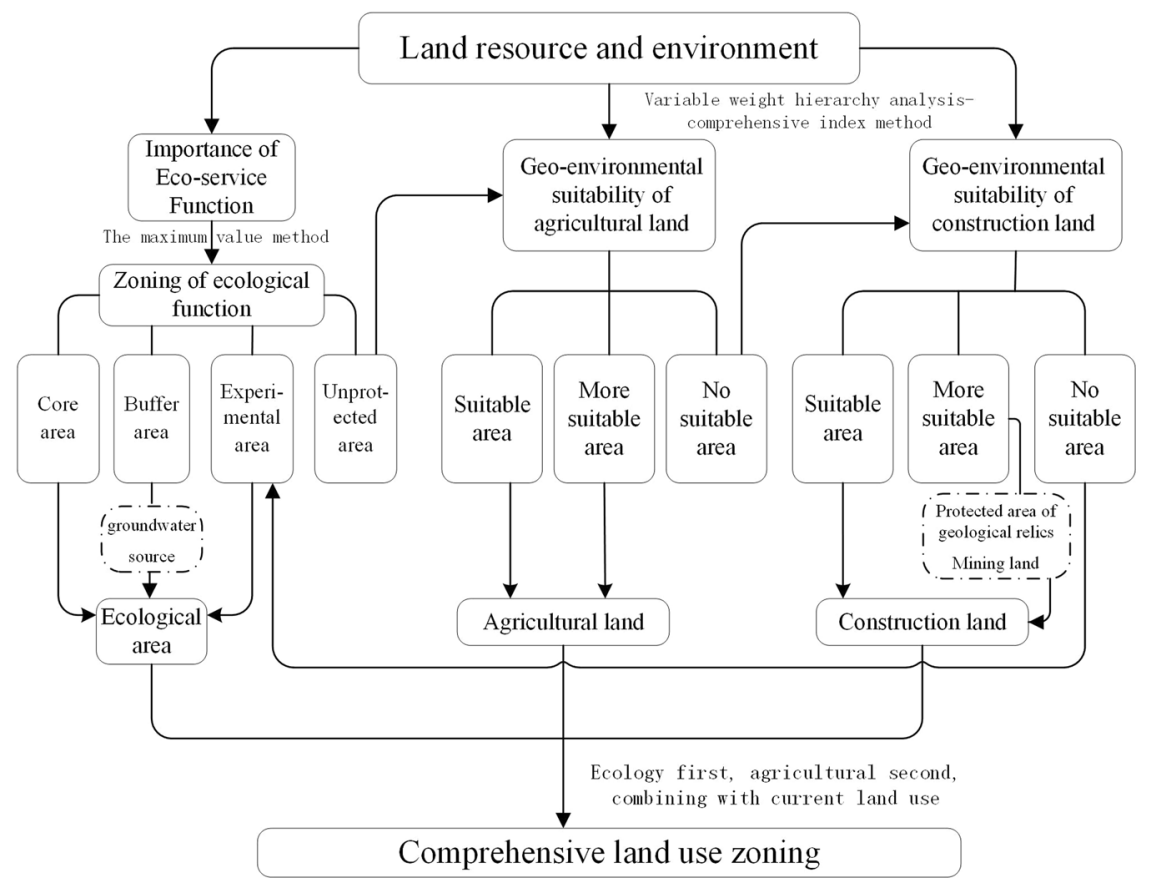

Figure 3. Flowchart of land utilization zoning in the study area.

\section{Methods}

Flowchart of this study is shown in Fig. 3. As illustrated in Fig. 3, the maximum value method was used to determine the importance of ecological service functions and the variable weight hierarchy analysis-comprehensive index method was used to the agricultural land and the construction land suitability, respectively. Special types of land utilization within the dotted frame has been reserved.

In order to ensuring the ecological security in the area, the study analyzes ecological security risk of the study area, and establishes an evaluation index system for the importance of ecological service functions comprising different single factors. With the support of MapGIS platform, the importance of each single ecological factor is separately segmented, and each single factor ecological service importance zoning map is superimposed. According to the objective weighting ${ }^{32,33}$ Eq. (1), the importance degree of the superimposed evaluation unit is determined, and the ecological protection zoning result of the study area is obtained.

$$
E I=M A X\left\{E I_{1}, E I_{2}, E I_{3}, \cdots \cdots E I_{i}\right\}
$$

where $E I$ is the ecological importance of the evaluation unit; $E I_{i}$ is the importance of each single factor ecological service.

From the perspective of geological environment, the suitability evaluation index systems which associated with agricultural land and construction land are established, respectively, and use AHP to determine the basic weight of evaluation index. Then use Eq. (2), the evaluation index forms orderly arrangement state according to the grouping of hierarchical structure, with 1-9 relative scale quantitative calculation ${ }^{11}$, through the comparison of the two indicators of the relative importance, the basis weight of each index is calculated. Then introduce the variable weight theory (VWT) ${ }^{28}$ to correct the basic weight Eqs (3) and (4) and solve the deviation of partial decision result in the weighted sum, so that the evaluation result is closer to the study reality.

$$
\begin{gathered}
M_{i j}^{\prime}=\frac{M_{i j}-\operatorname{Min}_{j}}{M a x_{j}-M i n_{j}} \\
K_{i j}=\left\{\begin{array}{cc}
1 & S_{i j}>A_{j} \\
e^{-\theta\left(S_{i j}-A_{j}\right)} & 0<S_{i j}<A_{j}
\end{array}\right. \\
S_{i j}^{\prime}=\frac{S_{i j} K_{i j}}{\sum_{i=1}^{n} S_{i j} K_{i j}}
\end{gathered}
$$

where $M^{\prime}{ }_{i j}$ is the score of the $\mathrm{j}$ index of the $\mathrm{i}$ evaluation unit after normalization, $M_{i j}$ is the actual score of the $\mathrm{j}$ indicator of the $i$ evaluation unit, $\operatorname{Max}_{j}$ and $\mathrm{Min}_{j}$ represent the maximum and minimum value of the $\mathrm{j}$ index actual score, $K_{i j}$ represents the weight correction coefficient of the j indicator of the i evaluation unit, and $\theta$ represents the 
degree of penalty of the variable weight. The greater the value is, the better the penalty effect is, $A_{j}$ indicates the critical value of the normalized value of the $\mathrm{j}$ indicator score after the descending order of two thirds, $S^{\prime}{ }_{i j}$ represents the weight correction value of the $\mathrm{j}$ index of the i evaluation unit, and $S_{i j}$ represents the basis weight of the $\mathrm{j}$ index of the i evaluation unit.

With the support of MapGIS platform, based on the suitability index grading standard of agricultural and construction land, the suitability evaluation of single index is carried out, and the new evaluation unit obtained from the superimpose the single index result, zoned by comprehensive index method (CIM) Eq. (5) for the agricultural land and the construction land suitability, respectively. Then, according to the suitability grading standard of agricultural and construction land, the results of the distribution of agricultural and construction land are obtained, respectively.

$$
P_{i}=\sum_{i=1}^{n} S_{i j}^{\prime} M_{i j}
$$

where $P_{i}$ represents the suitability score of i evaluation unit.

From the zoning results of agricultural and construction land, extract the land that play a special impact on the social and economic development, protected area of geological relics, mining land, protected area of groundwater resources, respectively, the zoning results of land utilization are obtained according to the determination standards.

Then comparing the distribution of land utilization status in the study area, considering the actual condition use status and suitability distribution of land, finally the comprehensive zoning of land utilization in the study area is put forward.

Zoning processes. Determination of land utilization types. The ecological land has the function of protecting the city's ecological system, biological habitat and improving the quality of life of the residents. The quantity and spatial distribution of ecological land will have an important influence on the urban ecological security ${ }^{34,35}$. Agriculture is the basic material guarantee of human survival and development, the rationality of its use is related to the sustainable development of human society. Construction land not only provides a basic space for human living environment but also carries a variety of human economic activities, which has a direct relationship on the size of urban land area and economic benefits of output. Based on the above considerations, determine the land resource function of the Pearl River Delta Economic Zone as: ecological land, agricultural land and construction land.

Ecological land zoning. Ecosystem provides human beings with a variety of services in both natural and subsistence environments. The sustainable supply of these services is the basis for economic and social development ${ }^{36-38}$. Due to the different geological environmental conditions, natural resources and living environments vary from region to region, it has been confirmed by previous studies ${ }^{39}$. For the Pearl River Delta Economic Zone, the service function of the ecosystem maintains the natural resource functions of biodiversity and water conservation, and provides the living environment functions of soil conservation and coastal protection.

Evaluation index system of ecosystem services functional importance. Biodiversity is the core of the ecosystem ${ }^{40}$, which supports all types of ecosystem service. The biodiversity will not only directly affect the ecosystem services function, but also one of the most critical indexes that constrain exerting of ecosystem services function ${ }^{41-44}$. The research selects natural reserves at different administrative levels as the basis for dividing the important of biodiversity conservation (Fig. 4a). Water conservation function is an important component of ecological function, its size affects the development of ecosystem ${ }^{45}$. Decline in water conservation can lead to the depletion of water resources ${ }^{46}$, which may have a devastating impact on ecosystem stability. The different vegetation types have different abilities for water conservation. According to different vegetation types, it combines the actual vegetation types in the study area to distinguish important water conservation function (Fig. 4b).

Soil erosion not only causes the loss of water and soil resources and the destruction of land productivity, but also the harm to human survival ${ }^{47-49}$. Due to soil erosion, ecological problems such as soil fertility decline have exacerbated the fragility of ecosystems and will affect human production and life (Fig. 4c). Coastal ecosystems have a protective effect against typhoons, waves and erosion ${ }^{50}$. Scientific and effective delineation of coastal zones is not only a green barrier against various threats but also plays an important role in maintaining ecological balance (Fig. 4d). According to the indicators grading standards of ecosystem services functional (Table 1), the important ecosystem services functional of each evaluation index is classified different levels.

Evaluation of importance of ecosystem services functional. Based on the MapGIS platform, the ecological service function importance zoning of each evaluation index is superimposed. Using Eq. (1) and according to Table 2, level of unit evaluation is determined, so that the ecological protected zones are obtained (Fig. 5).

$$
E I=\operatorname{Max}\left\{E I_{b d}, E I_{s y}, E I_{s l}, E I_{h d}\right\}
$$

where $E I$ is the ecological importance of unit, $E I_{\text {bd }}$ is biodiversity conservation, $E I_{\text {sy }}$ is water conservation, $E I_{\text {sl }}$ is soil erosion, and $E I_{\text {hd }}$ is coastal protected function.

Agricultural land zoning. The quality of agricultural geology and environmental conditions affect the safety of crops. Soil as a product of geological processes, which provide the growth of crops with the basic carrier conditions. Groundwater is an essential element of the growth of crops, and geomorphological conditions affect the suitability of crops. 

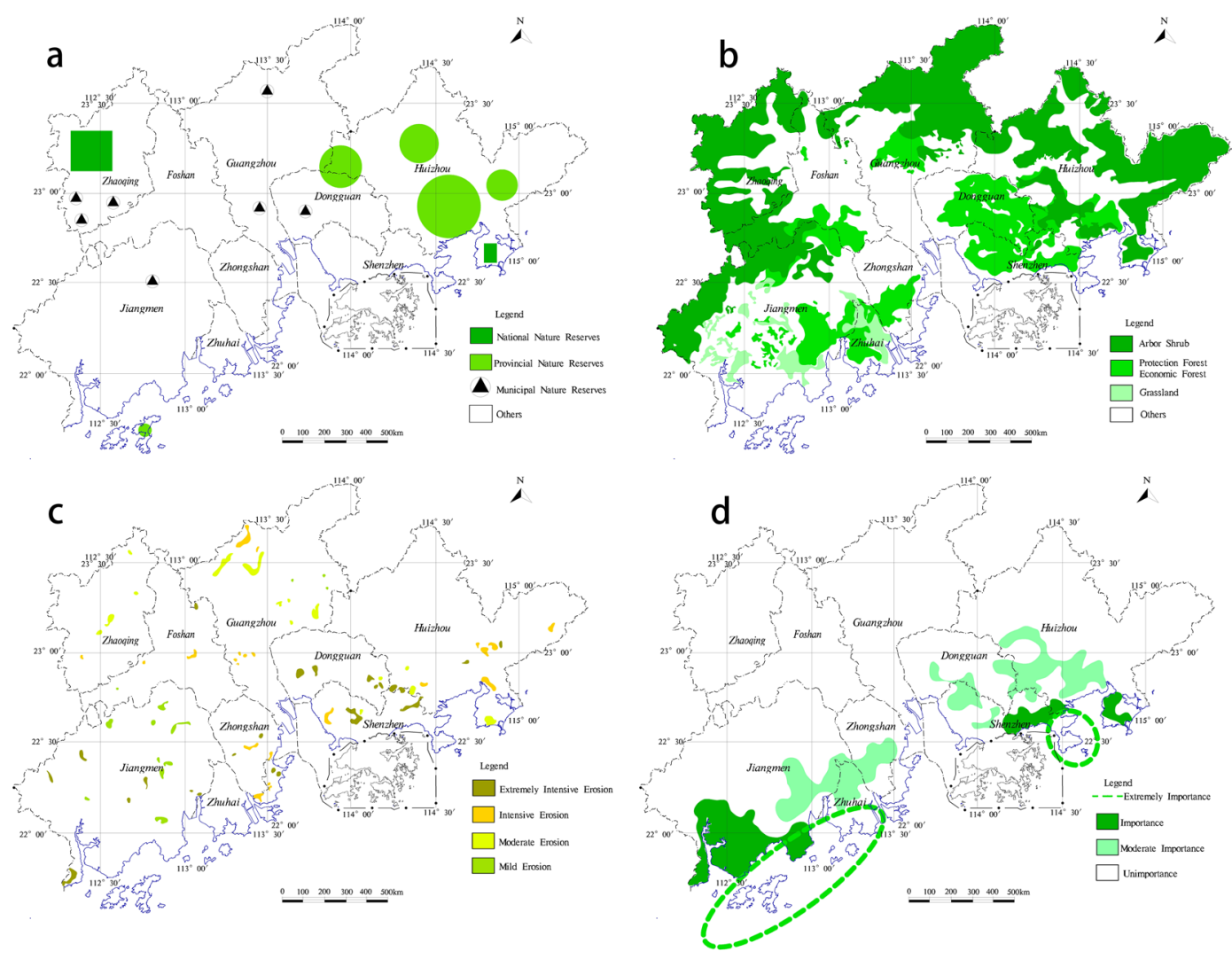

Figure 4. Each index important degree of ecosystem services functional. (a) Biodiversity importance; (b) Water conservation; (c) Soil erosion; (d) Coastal protected.

\begin{tabular}{|c|c|c|c|}
\hline Evaluation index & $\begin{array}{l}\text { The important degree of } \\
\text { ecological service function }\end{array}$ & Classification standards & Score \\
\hline \multirow{4}{*}{ Biodiversity conservation $\left(E I_{\mathrm{bq}}\right)$} & Extremely importance & National nature reserve & 100 \\
\hline & importance & Provincial nature reserves & 75 \\
\hline & Moderate importance & municipal nature reserves & 50 \\
\hline & unimportance & Others & 25 \\
\hline \multirow{4}{*}{ Water conservation $\left(E I_{\mathrm{sy}}\right)$} & Extremely importance & Arbor Shrubs & 100 \\
\hline & importance & Protected forest and Economic forest & 75 \\
\hline & Moderate importance & Grassland & 50 \\
\hline & unimportance & Others & 25 \\
\hline \multirow{4}{*}{ Soil erosion $\left(E I_{\mathrm{sl}}\right)$} & Extremely importance & Extremely intensive erosion & 100 \\
\hline & importance & Intensive erosion & 75 \\
\hline & Moderate importance & Moderate erosion & 50 \\
\hline & unimportance & Mild erosion & 25 \\
\hline \multirow{4}{*}{ Coastal zone protected function $\left(E I_{\mathrm{hd}}\right)$} & Extremely importance & Central Dayawan area and Daguanghai bay area & 100 \\
\hline & importance & Coastal zone and the island & 75 \\
\hline & Moderate importance & Coastal forest & 50 \\
\hline & unimportance & Others & 25 \\
\hline
\end{tabular}

Table 1. The evaluation index of importance of ecological service function.

Selecting evaluation index system of agricultural land suitability. In the evaluation index system of agricultural land, the landform is defined as the form and appearance of the surface ups and downs, because each landform has the characteristics of terrain slope, sediment soil and hydrological nature ${ }^{51}$. Therefore, the landform conditions determine the basic direction and layout of agricultural land utilization (Fig. 6a). The quality of groundwater will not only affect the quality of agricultural products but also play an important role in the consumption rate of soil organic matter and the capacity of soil regeneration ${ }^{52}$ (Fig. 6b). Precipitation is the main limiting index for the growth of crops (Fig. 6c). If the crop roots absorption heavy metal elements in the soil, thus it will affect human health. Combined with the actual soil conditions of the study area, and select the abnormal heavy metal elements 


\begin{tabular}{|l|l|}
\hline Classification standards & EI \\
\hline Core area & 100 \\
\hline Buffer area & 75 \\
\hline Experimental area & 50 \\
\hline Unprotected area & 25 \\
\hline
\end{tabular}

Table 2. The classification standards of ecological protection zoning.

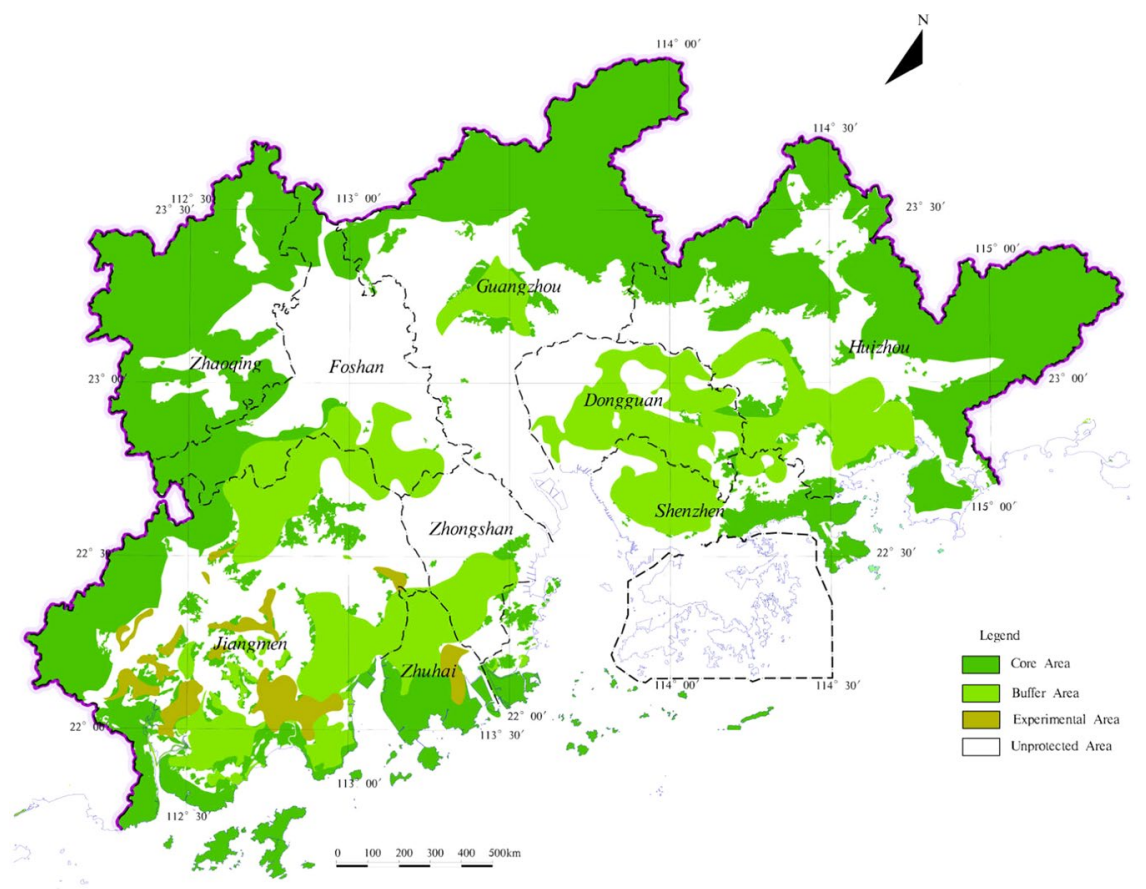

Figure 5. The ecological protection zoning in the study area.

of As (Fig. 6d), Hg (Fig. 6e) and Cd (Fig. 6f) as the evaluation index ${ }^{30,53}$. For most study areas, the increase in precipitation is appropriate, which is conducive to the growth and development of crops and improve the regional agricultural productivity. Therefore, in the agricultural land suitability evaluation, select the geological indexes that affect the growth of crops as the evaluation index (Table 3).

Construction land zoning. The relationship between geological environment and the construction land is the complex interaction. On the one hand, urban safety is the basic condition of human survival, and the suitability of geological environment conditions determine the safety of urban construction. Besides, urban construction process is also transforming the surrounding geological environment, which may lead to the deteriorate of regional geological conditions or exacerbate occur adverse geological effects, so it will affect the survival safety.

Evaluation index system of construction land suitability. In the evaluation index system of construction land suitability, the landforms affect the determination of urban location, selection of urban construction site, zoning layout, engineering facilities, layout of construction and other aspects. Because the terrain is flat, which is favorable to develop urban construction, and the terrain slope of the larger hills and mountain areas, where difficulty of urban construction has increased significantly, so the landforms has an important impact on construction land zoning (Fig. 7a). The level of groundwater mineralization reflects the corrosive nature of anions and cations for underground infrastructure to affect the safety and stability of the buildings (Fig. 7b). The area where karst water distributed is a high prone area for ground collapse, which endangers the safety of surface buildings (Fig. 7c). The fault condition reflects the structural stability of the area. Owing to fault slip, buildings on active faults after the earthquake, which is more prone to damage (Fig. 7d). Ground subsidence can cause the foundation to be disturbed and destroyed, which can cause the buildings to tilt, wall cracking, and even affect the normal use (Fig. 7e $)^{54}$. The higher the degree of geological hazards, the greater the likelihood of damage to buildings (Fig. 7f). The type of foundation soil is directly related to the stability of the foundation, the clay soil is prone to shear failure under the action of the load, and the liquefiable soil can cause the foundation failure during the earthquake, muddy soil with stand lower loads, which is more prone to ground subsidence (Fig. 7g). Therefore, from the 

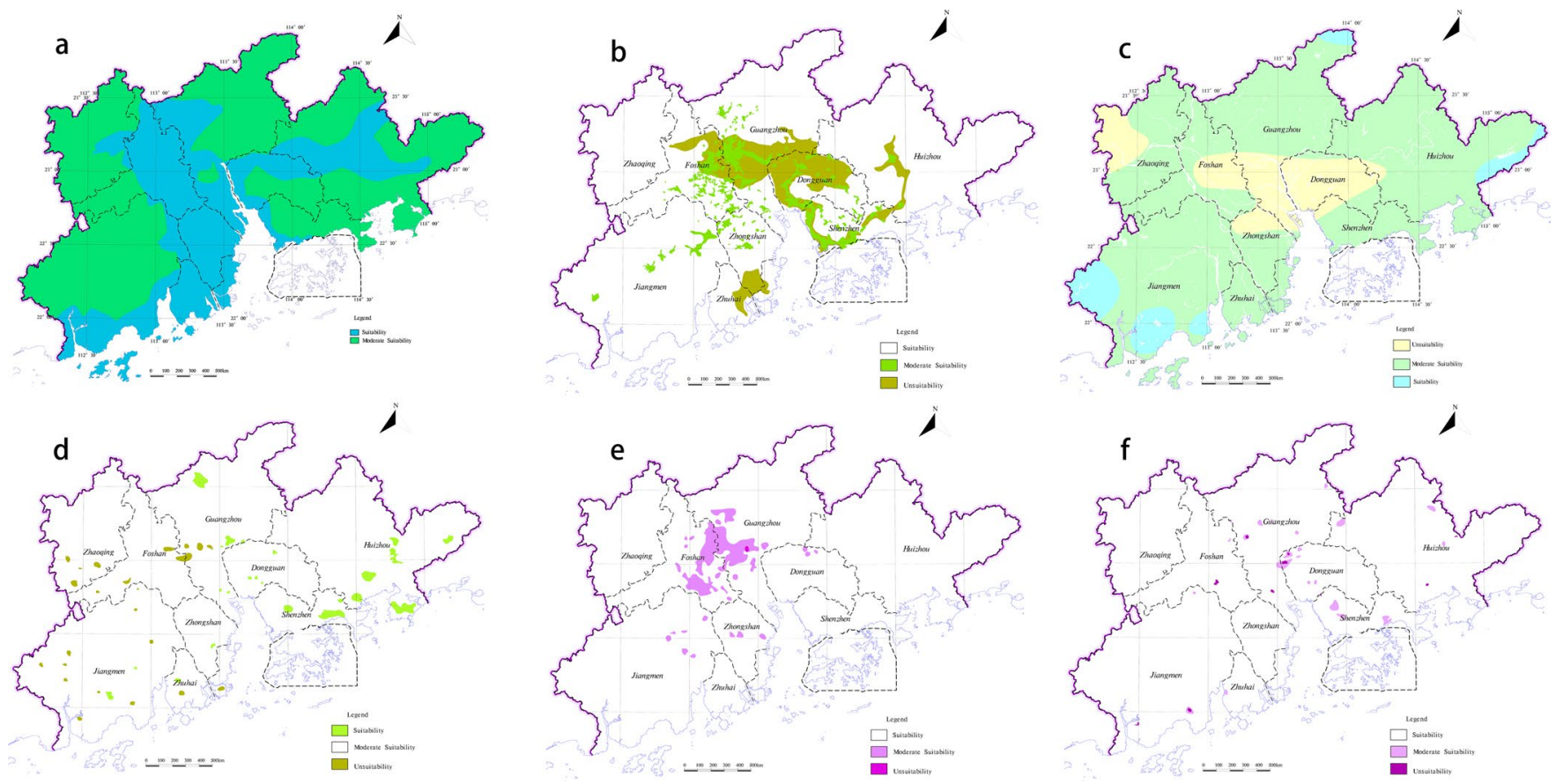

Figure 6. The agricultural land suitability evaluation of each index. (a) Landscapes; (b) Rainfall; (c) Groundwater pollution; (d) Arsenic; (e) Mercury; (f) Chromium.

\begin{tabular}{|c|c|c|c|c|c|c|c|c|}
\hline Criterion & $\begin{array}{l}\text { Constant } \\
\text { weights }\end{array}$ & \begin{tabular}{|l} 
Variable \\
weights
\end{tabular} & Evaluation index & Suitability (5) & $\begin{array}{l}\text { Moderate Suitability } \\
\text { (3) }\end{array}$ & Unsuitability (1) & $\begin{array}{l}\text { Constant } \\
\text { weights }\end{array}$ & $\begin{array}{l}\text { Variable } \\
\text { weights }\end{array}$ \\
\hline \multirow[b]{2}{*}{ Natural geography } & \multirow[b]{2}{*}{0.252} & \multirow[b]{2}{*}{0.259} & Geomorphology & Plain & Hills & Mountain & 0.121 & 0.125 \\
\hline & & & $\begin{array}{l}\text { Annual precipitation } \\
(\mathrm{mm} / \mathrm{a})\end{array}$ & $>2200$ & $1600-2200$ & $<1600$ & 0.131 & 0.134 \\
\hline Water quality & 0.233 & 0.224 & Groundwater pollution & Uncontamination & Slight contamination & Heavy contamination & 0.233 & 0.224 \\
\hline \multirow{3}{*}{ Soil quality } & \multirow{3}{*}{0.515} & \multirow{3}{*}{0.517} & Arsenic (PPM) & $<40$ & $40-80$ & $>80$ & 0.175 & 0.174 \\
\hline & & & Mercury (PPM) & $<0.5$ & $0.5-3$ & $>3$ & 0.171 & 0.172 \\
\hline & & & Chromium (PPM) & $<15$ & $90-300$ & $>300$ & 0.169 & 0.171 \\
\hline
\end{tabular}

Table 3. Evaluation index of suitability of agricultural land.

perspective of geological environment which affects the safety of urban land construction, selects the suitability evaluation index system of construction land (Table 4).

Zoning and evaluation of agricultural land and construction land. Based on the present conditions of evaluation index of suitability, according to the evaluation index grading standard of agricultural land, construction land (Tables 3,4), with the support of MapGIS platform, the research superimposes each suitability index zoning results (Figs 6, and 7). And use the attribute boundary of each evaluation index after superimposition serves as the evaluation unit. Then introduce the VWAHP-CIM calculate each evaluation unit score of suitability. According to the land suitability evaluation type of grading criteria (Table 5), the results of land suitability zoning are got in the study area (Figs 8, and 9).

Special types of land utilization. Based on the actual conditions of land utilization in the study area, the mining land, protected area of geological relics and protected area of groundwater resources are extracted separately, which have special effects on local social economic development and ecological security.

Mineral resources and land resources are essential for human survival and social development of the means of production. The exploitation of mineral resources stimulates the local socio-economic development, meanwhile, the exploitation of mineral resources damages the arable land resources. The non-metallic mineral resources are the main mineral resources in the study area. And although the study area has a large variety of minerals, yet the scale of mineral resources is smaller, which is mostly distributed in hilly areas outside the study area where the ecological environment more superior (Fig. 10). Furthermore, mineral exploitation is relatively great difficulty and causes large damage to ecological environment. Geological relics are non-renewable, geological and natural heritage, with important scientific value and social value. Geological relics not only promote tourism 

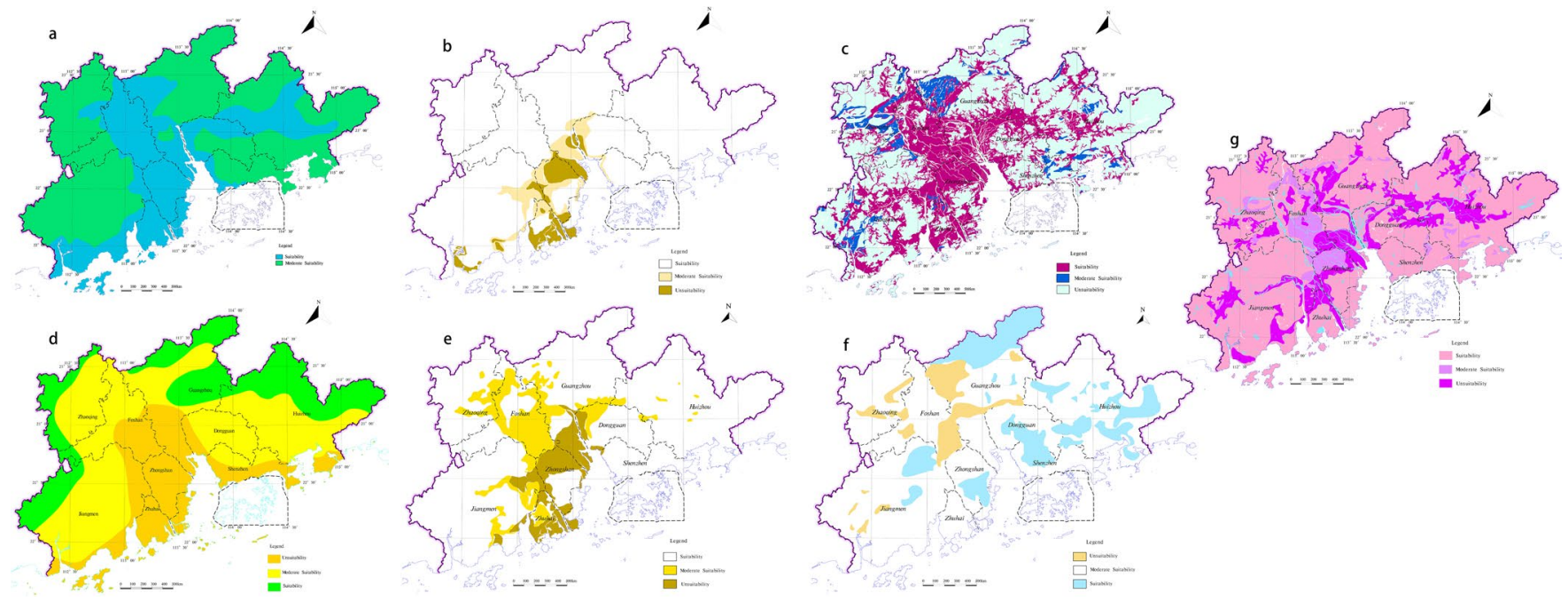

Figure 7. The construction land suitability evaluation of each index. (a) Landscapes; (b) Groundwater; (c) Salt water; (d) Fracture; (e) Ground subsidence; (f) Foundation soil; (g) Geohazards probability.

\begin{tabular}{|c|c|c|c|c|c|c|c|c|}
\hline Criterion & $\begin{array}{l}\text { Constant } \\
\text { weights }\end{array}$ & $\begin{array}{l}\text { Variable } \\
\text { weights }\end{array}$ & Evaluation index & Suitability (5) & Moderate Suitability (3) & Unsuitability (1) & $\begin{array}{l}\text { Constant } \\
\text { weights }\end{array}$ & $\begin{array}{l}\text { Variable } \\
\text { weights }\end{array}$ \\
\hline Natural geography & 0.113 & 0.115 & Geomorphology & Plain & Hills & Mountain & 0.113 & 0.115 \\
\hline \multirow{2}{*}{ Hydrogeology } & \multirow{2}{*}{0.263} & \multirow{2}{*}{0.264} & Type of groundwater & Pore water & Interstitial water & Karst water & 0.117 & 0.119 \\
\hline & & & Saline water (TDS) & $<1 \mathrm{~g}$ & $1-10 \mathrm{~g}$ & $>10 \mathrm{~g}$ & 0.146 & 0.145 \\
\hline \multirow{3}{*}{ Engineering Geology } & \multirow{3}{*}{0.488} & \multirow{3}{*}{0.484} & Fracture & No development & General development & Development & 0.177 & 0.173 \\
\hline & & & Ground subsidence & $\begin{array}{l}\text { Area of no ground } \\
\text { subsidence }\end{array}$ & $\begin{array}{l}\text { Area of soft soil } \\
\text { distribution }\end{array}$ & $\begin{array}{l}\text { Area of ground } \\
\text { subsidence prone }\end{array}$ & 0.163 & 0.161 \\
\hline & & & Foundation soil & Rocks & Gravel and sand & $\begin{array}{l}\text { Mucky soil and } \\
\text { cohesive soil }\end{array}$ & 0.148 & 0.150 \\
\hline Environmental geology & 0.136 & 0.137 & $\begin{array}{l}\text { Geological hazard } \\
\text { probability }\end{array}$ & $\begin{array}{l}\text { Low-probable } \\
\text { geological hazard }\end{array}$ & $\begin{array}{l}\text { Mid-probable geological } \\
\text { hazard }\end{array}$ & $\begin{array}{l}\text { High-probable } \\
\text { geological hazard }\end{array}$ & 0.136 & 0.137 \\
\hline
\end{tabular}

Table 4. The evaluation index of suitability of construction land.

\begin{tabular}{|l|l|l|l|}
\hline $\begin{array}{l}\text { Suitability } \\
\text { score }\end{array}$ & $<\mathbf{2}$ & $\mathbf{2 - 4}$ & $>\mathbf{4}$ \\
\hline Suitability level & Unsuitability & Moderate Suitability & Suitability \\
\hline
\end{tabular}

Table 5. The classification standards of suitability evaluation

development but also play an important role in improving the quality of regional ecological environment ${ }^{55}$. As the destruction of geological relics by exploitation of mineral resources and other human indexes are becoming increasingly serious ${ }^{56}$, geological relics of exploitation and management should be based on the protected (Fig. 11). In addition to retaining the mining land and protected area of geological relics distributed on the construction land, respectively, the rest is classified into the corresponding land types. With the industrial development, the groundwater environment is suffered serious damage ${ }^{57}$, it directly relates the groundwater quality in protected area of groundwater resources and the local drinking water safety. The contamination of groundwater with hidden and difficult control properties, so the groundwater resources area should be protected in advance (Fig. 12). This study directly divides the type of groundwater source into an ecological land buffer.

\section{Results and Discussion}

According to the determination steps of land utilization and Fig. 3, the zoning results of different land utilization types are superimposed by method of MapGIS platform, and the result of land utilization zoning is got in the study area (Fig. 13).

Based on the result of the land utilization zoning, the study analyses the distribution characteristics of the land utilization types, considered the suitability distribution of different land utilization types, the actual conditions, the regional function orientation and the requirement of ecological construction, the comprehensive zoning of land utilization in the study area is got (Fig. 14). 


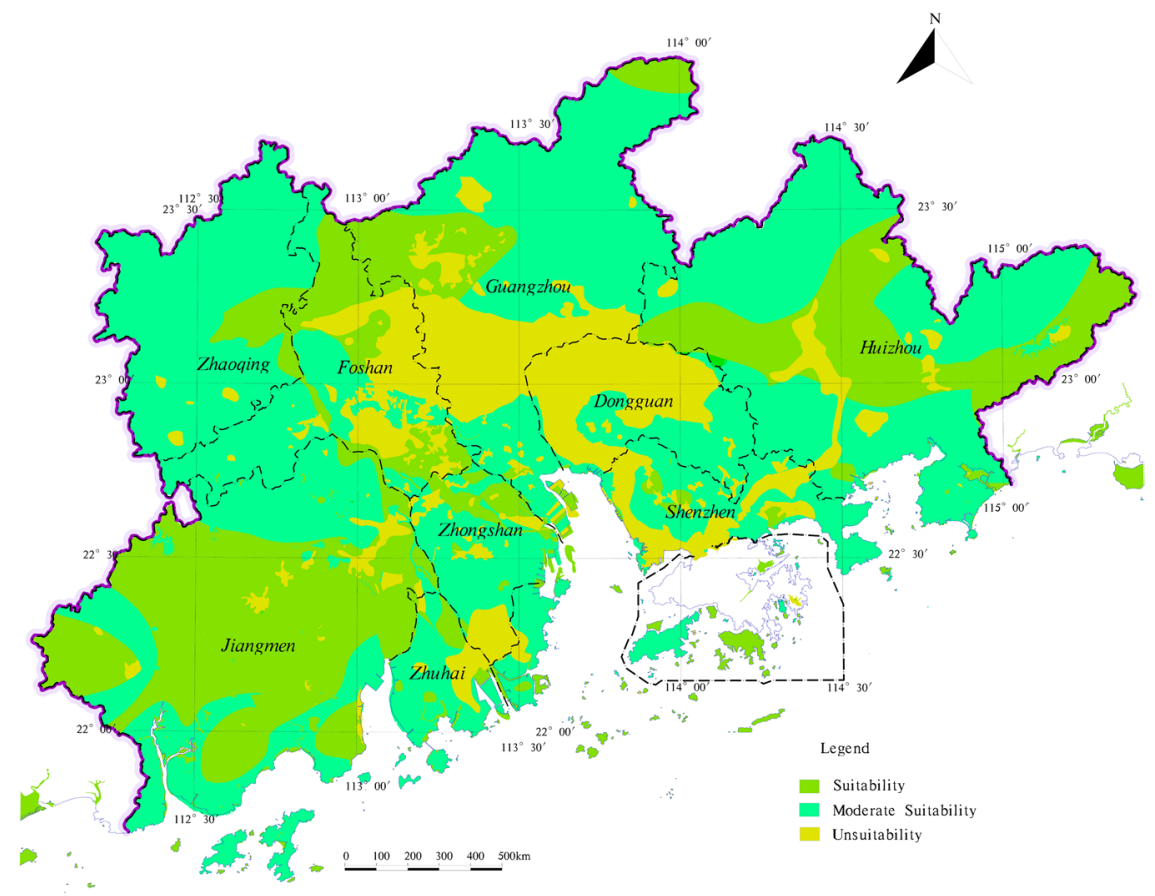

Figure 8. The zoning of agricultural land suitability evaluation in the study area.

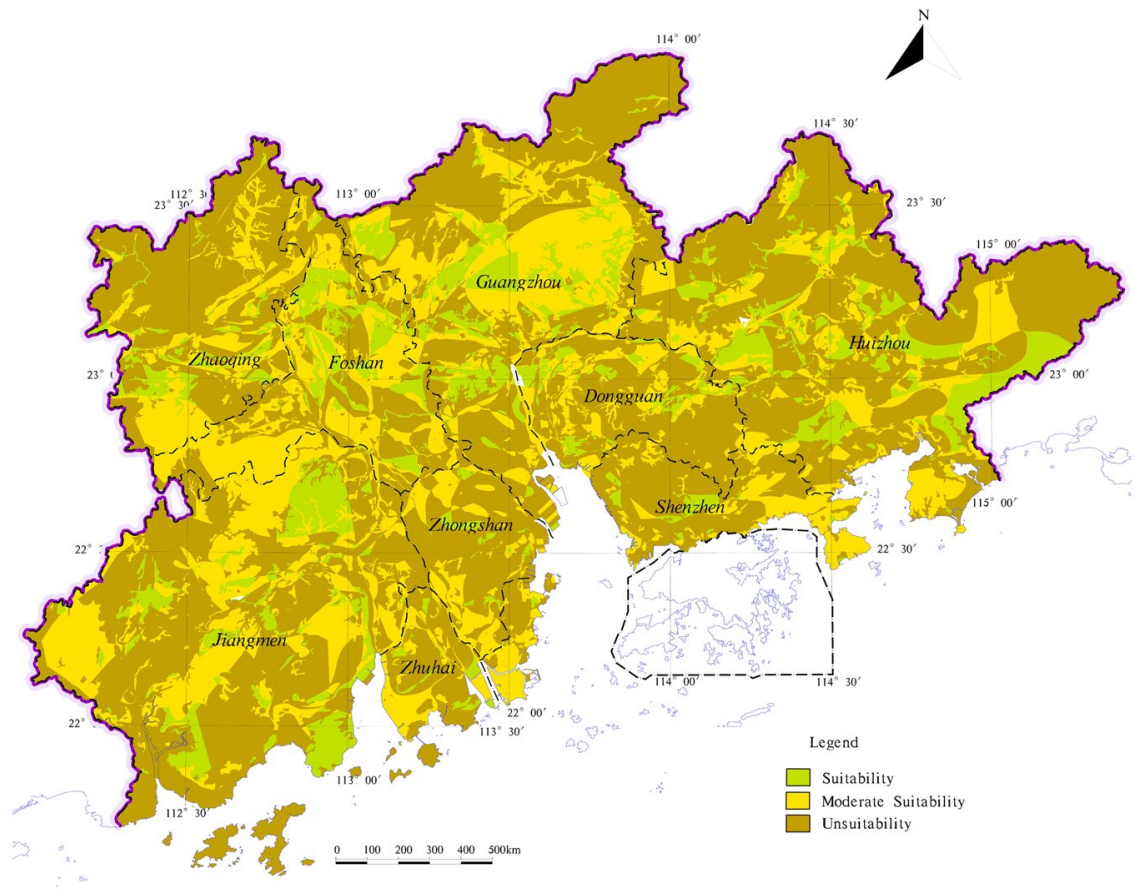

Figure 9. The zoning of construction land suitability in the study area.

Agricultural land is widely distributed in areas with flat terrain within the study area. The low hills surrounding the study area, the terrain has a large slope, less agricultural land; The land with high agricultural suitability in the study area is mostly distributed in Jiangmen City and Huizhou City. The terrain has small slope, superior climatic conditions, good water quality conditions, superior location conditions, a certain agricultural foundation and suitable for large-scale mechanized operation of agriculture. For some moderate suitable agricultural land distribution in the northern part of the study area, due to scattered distribution and difficult development, on the premise that it cannot be converted into construction land, it should be classified as ecological land. In Guangzhou City, Foshan City and Dongguan City, where economic development is high, water and soil are highly polluted, and they are more easily absorbed by crops, thus affecting human health. At the same time, the population density in this area is highly 


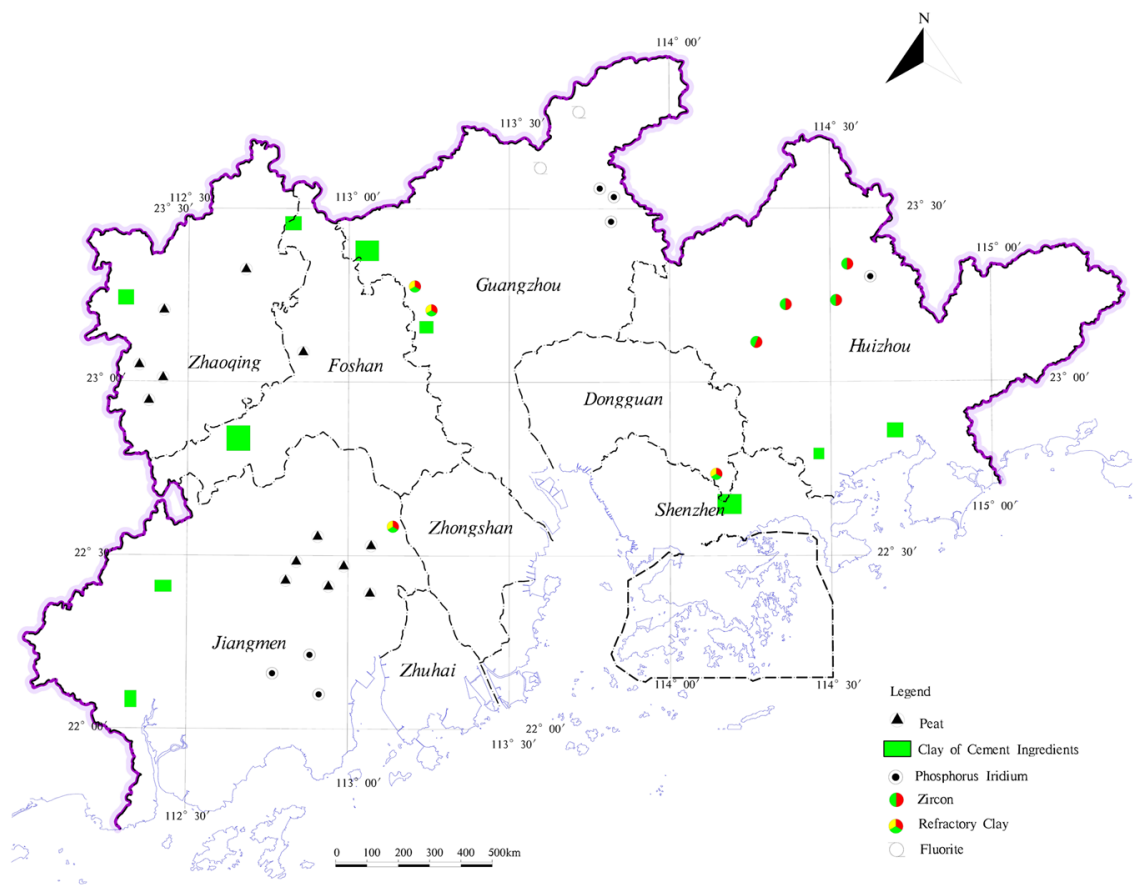

Figure 10. The distribution of mineral resources in the study area.

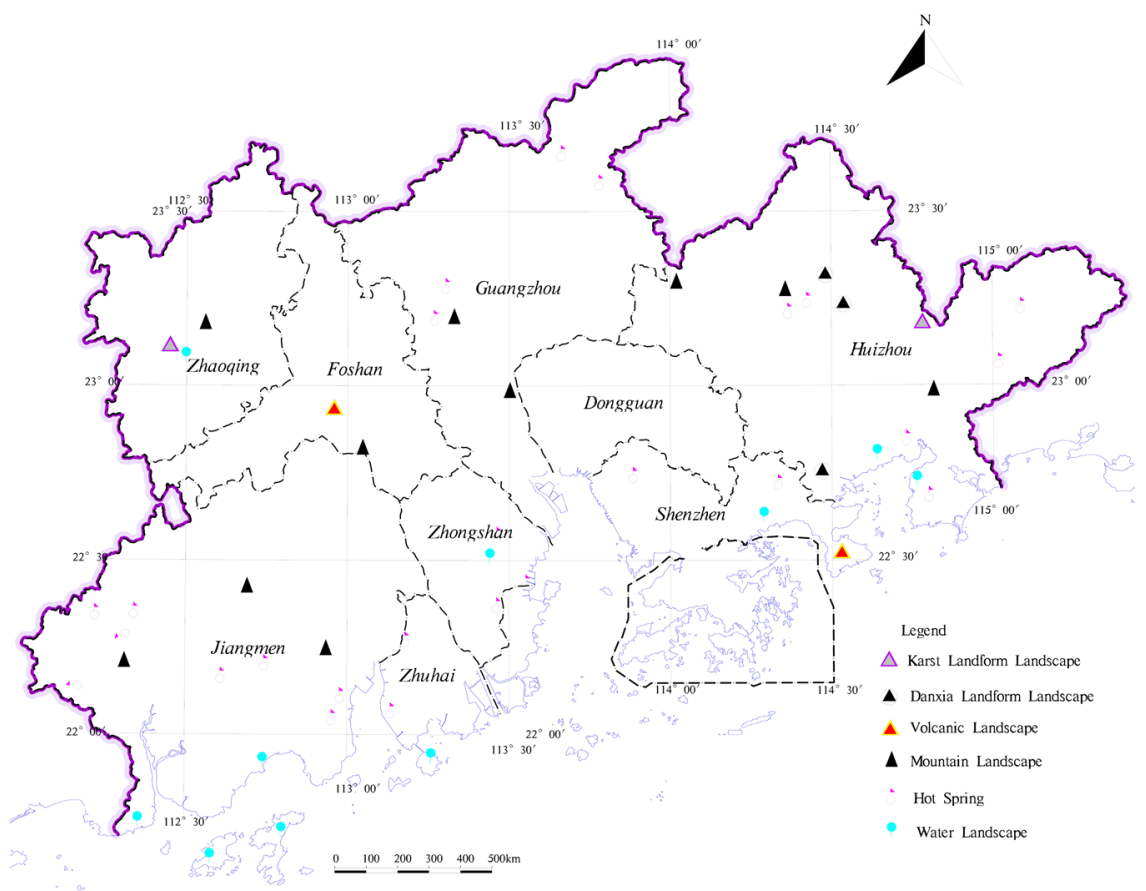

Figure 11. The distribution of geological relics in the study area.

concentrated, the per capita construction land area is low, part of the agricultural land in this region is divided into construction land to alleviate the tension between the supply and demand of the people in the study area. In addition, to maintain the stability of the ecosystem within the study area, some of the circular peripheral ecological core areas are occupied by agricultural land under realistic conditions, such areas should actively implement the policy of "returning farmland to forests" to guide the transformation of agricultural land to ecological land. 


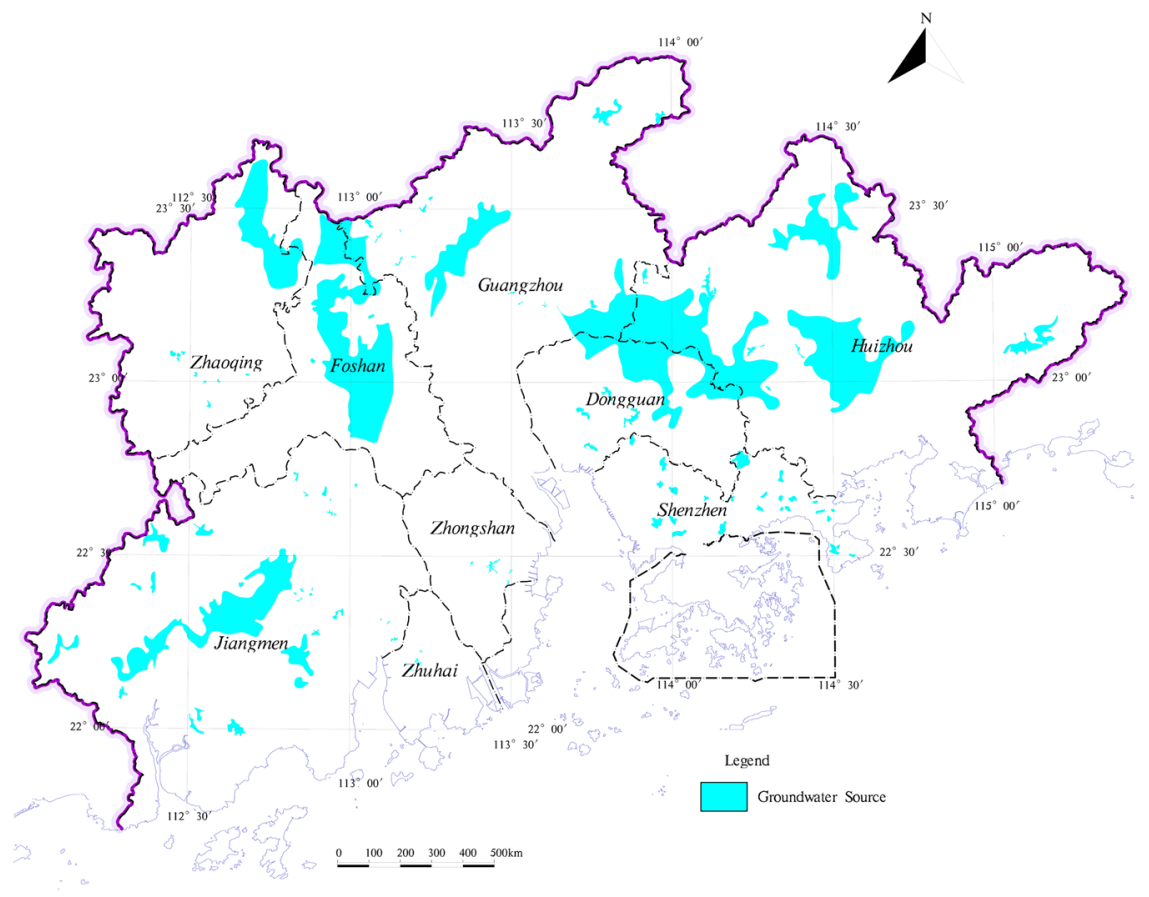

Figure 12. The distribution of groundwater source field in the study area.

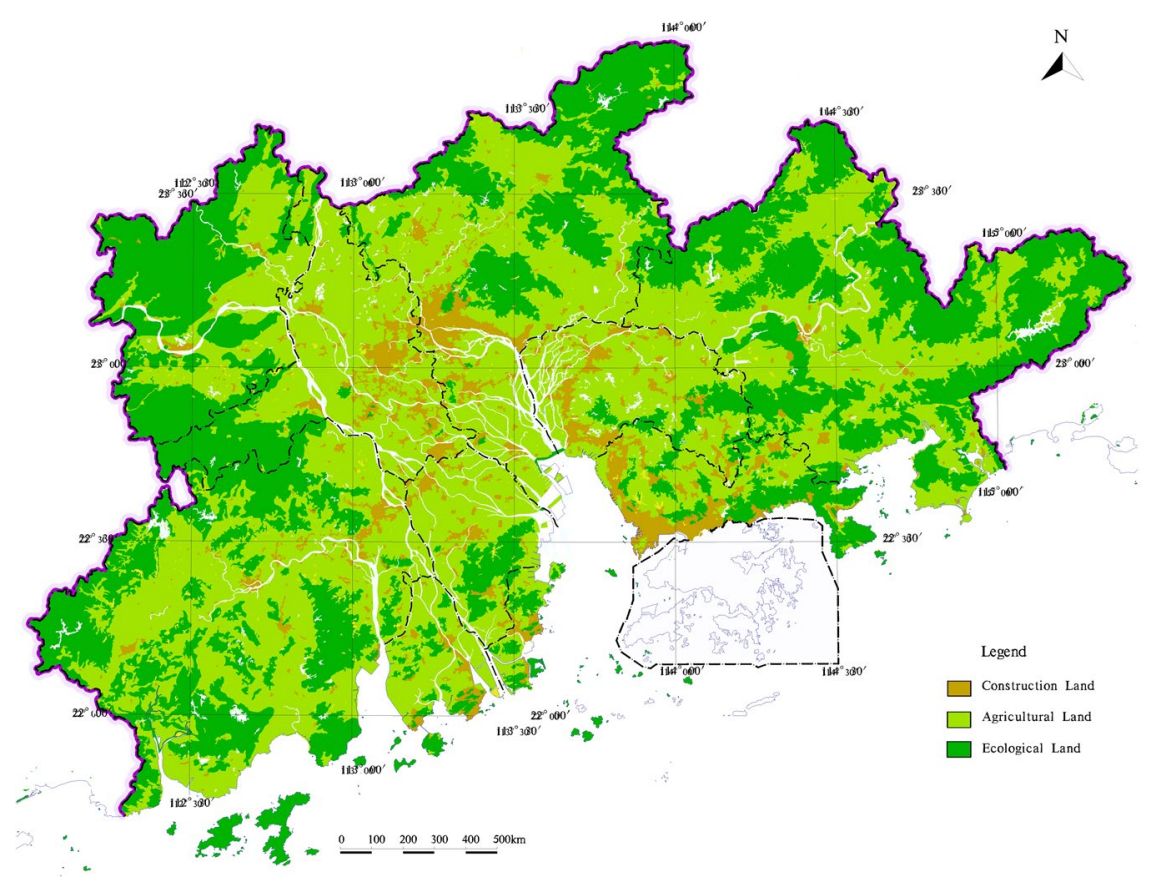

Figure 13. The zoning of land utilization in the study area.

\section{Conclusions}

Rapid urbanization has brought serious geological environmental problems, land resource utilization seriously restricts social development. Taking Pearl River Delta Economic Zone as an example, a variable weight-analytical hierarchy process-comprehensive index evaluation model was proposed to land utilization types zoning. In this process, based on 1:250000 Pearl River Delta Geological Survey Data, the model takes ecological protection zoning for the study area from assessing the importance of ecological service function in four aspects: biodiversity, water conservation, soil conservation and coastal zone protection. Based on this, the evaluation index system was established from the perspective of geological environment to evaluate the suitability of agricultural land and 


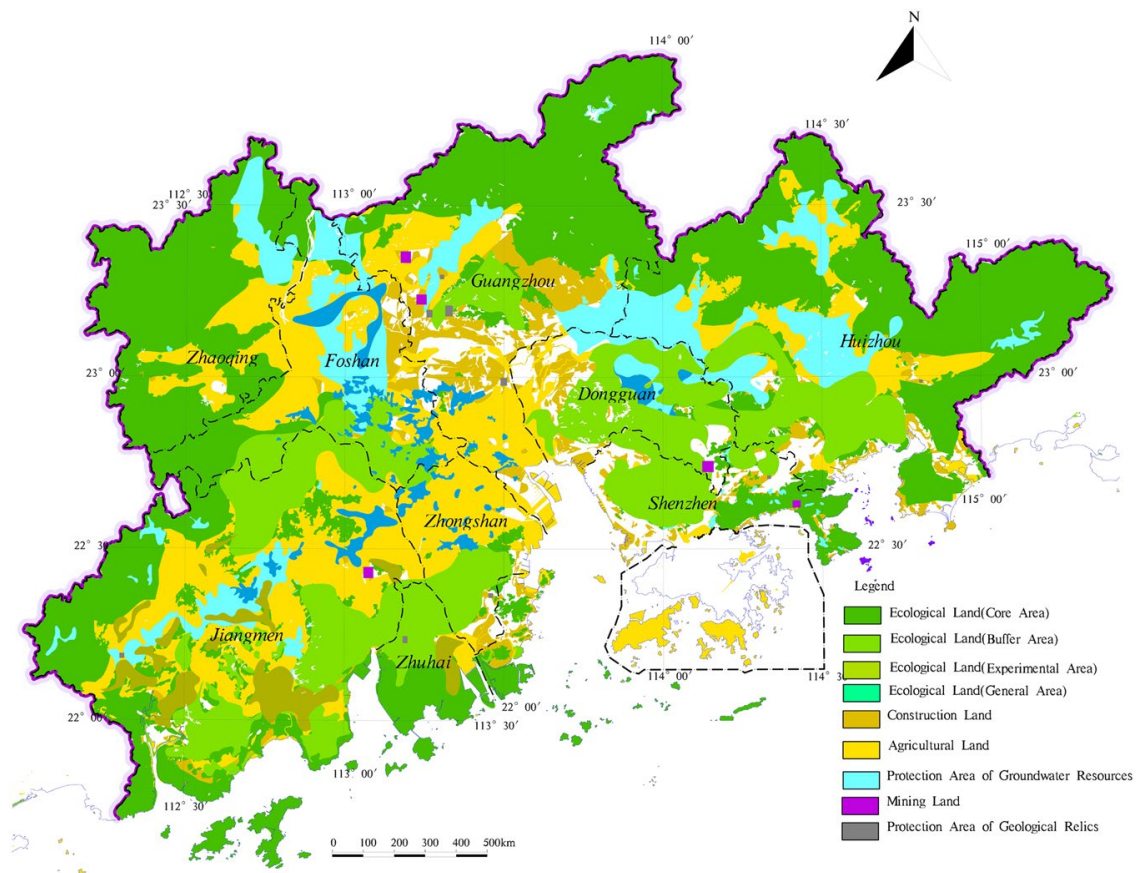

Figure 14. The comprehensive zoning of land utilization in the study area.

construction land. And re-zoning the type of land that has a special effect on the socio-economic and the ecology. According to the actual land utilization status and land suitability distribution, the results of land utilization zoning is got. The results showed that the area of ecological land, agricultural land and construction area in the study area accounted for $64.8 \%, 25.1 \%$, and $10.1 \%$ of the total area of the study area, respectively.

Overall, the results show that the current land utilization in the Pearl River Delta is unreasonable because it does not consider geological environmental conditions, resulting in a decline in ecological service functions. This study provides an experience for regional zoning of multiple land utilization types. The method proposed in this paper, which applies future land utilization zoning in the study area and it can be recommended to conduct regional zoning for deterioration of ecological environment and the intensification of conflicts between people and land.

\section{Data availability}

The relevant datasets in this study are available from the corresponding author on reasonable request.

Received: 19 March 2019; Accepted: 10 October 2019;

Published online: 05 November 2019

\section{References}

1. Chen-Jing, F., Shi-Guang, S., Si-Hui, W., Guang-Hui, S. \& Xin-Yi, W. Research On Urban Land Ecological Suitability Evaluation Based On Gravity-Resistance Model: A Case of Deyang City in China. Procedia Engineering. 21 (2011).

2. Onishi, T. A Capacity Approach for Sustainable Urban. Development: An Empirical Study. 28, 39-51 (1994)

3. Pan, J. \& Wei, H. Annual Report On Urban Development of China 2013. Current Chinese Economic Report. (2015).

4. Zhang, H. \& Xu, E. An Evaluation of the Ecological and Environmental Security On China'S Terrestrial Ecosystems. Sci. Rep.-UK. 7 (2017).

5. Vennemo, H., Aunan, K., Lindhjem, H. \& Seip, H. M. Environmental Pollution in China: Status and Trends. Review of Environmental Economics and Policy. 3, 209-230 (2009).

6. Zhao, H., Wang, X., Cai, Y. \& Liu, W. Wetland Transitions and Protection under Rapid Urban Expansion: A Case Study of Pearl River Estuary, China. Sustainability-Basel. 8, 471 (2016).

7. Dong, H. et al. The Controlling Factors of Environment Geology in the Pearl River Delta Economic Zone and an Analysis of Existing Problems (In Chinese). Geology in China. 2, 539-550 (2012).

8. Xia-Jie, Z. \& Qi-You, C. Review and Outlook of the Research on Land Use Regionalization in China (In Chinese). China Land Science. 62-68 (2008).

9. Morteza, Z., Reza, F. M., Seddiq, M. M., Sharareh, P. \& Jamal, G. Selection of the Optimal Tourism Site Using the ANP and Fuzzy TOPSIS in the Framework of Integrated Coastal Zone Management: A Case of Qeshm Island. Ocean Coast. Manage. 130, 179-187 (2016).

10. Ya, G., Li-Jie, P., Yao-Yang, Z. \& Xiao-Tian, H. Review and Prosrects of Land Use Zoning Research (In Chinese). Resources and Environment in the Yangtze Basin. 759-763 (2007).

11. Saaty, H. L. A Scaling Method for Priorities in Hierarchical Structures. Journal of Mathematical Psychology. 234-281 (1977).

12. Van der Merwe, J. H. GIS-aided Land Evaluation and Decision-Making for Regulating Urban Expansion: A South African Case Study. GeoJournal. 135-151 (1997).

13. Ferraz, A. et al. Airborne Lidar Estimation of Aboveground Forest Biomass in the Absence of Field Inventory. Remote Sens.-Basel. 8, 653 (2016).

14. Song, S. et al. Balancing Conservation and Development in Winter Olympic Construction: Evidence From a Multi-Scale Ecological Suitability Assessment. Sci. Rep.-UK. 8 (2018). 
15. Peng, J., Du, Y., Liu, Y. \& Hu, X. How to Assess Urban Development Potential in Mountain Areas? An Approach of Ecological Carrying Capacity in the View of Coupled Human and Natural Systems. Ecol. Indic. 60, 1017-1030 (2016).

16. Baja, S., Chapman, D. M. \& Dragovich, D. Spatial Based Compromise Programming for Multiple Criteria Decision Making in Land Use Planning. Environ. Model. Assess. 12, 171-184 (2007).

17. Ceballos-Silva, A. \& López-Blanco, J. Delineation of Suitable Areas for Crops Using a Multi-Criteria Evaluation Approach and Land Use/Cover Mapping: A Case Study in Central Mexico. Agr. Syst. 77, 117-136 (2003).

18. Giap, D. H., Yi, Y. \& Yakupitiyage, A. GIS for Land Evaluation for Shrimp Farming in Haiphong of Vietnam. Ocean Coast. Manage. 48, 51-63 (2005).

19. Liu, Y., Jiao, L., Liu, Y. \& He, J. A Self-Adapting Fuzzy Inference System for the Evaluation of Agricultural Land. Environ. Modell. Softw. 40, 226-234 (2013).

20. Hogg, O. T., Huvenne, V. A. I., Griffiths, H. J., Dorschel, B. \& Linse, K. Landscape Mapping at sub-Antarctic South Georgia Provides a Protocol for Underpinning Large-Scale Marine Protected Areas. Sci. Rep.-UK. 6 (2016).

21. Bhanja, S. N. et al. Groundwater Rejuvenation in Parts of India Influenced by Water-Policy Change Implementation. Sci. Rep.-UK. 7 (2017).

22. Wright, H. Understanding Green Infrastructure: The Development of a Contested Concept in England. 16 1003-1019 (2011).

23. Pataki, D. E. et al. Coupling Biogeochemical Cycles in Urban Environments: Ecosystem Services. Green Solutions, and Misconceptions. 9, 27-36 (2011).

24. Klemm, W., Heusinkveld, B. G., Lenzholzer, S. \& van Hove, B. Street Greenery and its Physical and Psychological Impact On Thermal Comfort. Landscape Urban Plan. 138, 87-98 (2015).

25. Yu, D. et al. The Development of Land Use Planning Scenarios Based On Land Suitability and its Influences On Eco-Hydrological Responses in the Upstream of the Huaihe River Basin. Ecol. Model. 373, 53-67 (2018).

26. Siiba, A., Adams, E. A. \& Cobbinah, P. B. Chieftaincy and Sustainable Urban Land Use Planning in Yendi, Ghana: Towards Congruence. Cities. 73, 96-105 (2018).

27. Rannow, S., Loibl, W., Greiving, S., Gruehn, D. \& Meyer, B. C. Potential Impacts of Climate Change in Germany-Identifying Regional Priorities for Adaptation Activities in Spatial Planning. Landscape Urban Plan. 98, 160-171 (2010).

28. Bao-Chen, Y. \& Yue, C. Grey Relational Decision-Making Model Based on Variable Weight and TOPSIS Method (In Chinese). Systems Eng. 106-112 (2011).

29. Han, X., Pan, J. \& Devlin, A. T. Remote Sensing Study of Wetlands in the Pearl River Delta During 1995-2015 with the Support Vector Machine Method. Front. Earth Sci.-PRC. 12, 521-531 (2018).

30. Huang, G., Zhang, M., Liu, C., Li, L. \& Chen, Z. Heavy Metal(Loid)s and Organic Contaminants in Groundwater in the Pearl River Delta that Has Undergone Three Decades of Urbanization and Industrialization: Distributions, Sources, and Driving Forces. Sci. Total Environ. 635, 913-925 (2018).

31. Ye, L. et al. Wet and Dry Deposition Fluxes of Heavy Metals in Pearl River Delta Region (China): Characteristics, Ecological Risk Assessment, and Source Apportionment. J. Environ. Sci.-China. 70, 106-123 (2018).

32. Zhenxing, Z., Yanhui, L. \& Guangxiang, Y. Reviews On Vulnerability Assessment Methods for Geo-Hazards (In Chinese). The Chinese Journal of Geological Hazard and Control. 29 (2018).

33. Lili, S. \& Jianping, Q. Vulnerability Evaluation On Egional Landslides Based On GIS and Contribution Weight Superposition Approach (In Chinese). Journal of Catastrophology. 3, 46-50 (2009).

34. Feng, L., Ya-Ping, Y., Bo-Wen, S. \& Ru-Song, W. Spatial Structure of UrbanE Land and its Dynamic Development of Ecosystem Services: A case study in Changzhou City (In Chinese). Acta Ecologica Sinica. 5623-5631 (2011).

35. Wei-Zhong, S., Gui-Shan, Y. \& Feng, Z. Ecological Land Fragmentation and its Connectivity with Urbanization in the Yangtze River Delta (In Chinese). Acta Geographica Sinica. 1309-1317 (2007).

36. Costanza, R. et al. The Value of the World's Ecosystem Services and Natural Capital. Ecol. Econ. 25 (1998).

37. Daily, G. C. et al. Ecosystem Services in Decision Making: Time to Deliver. Front. Ecol. Environ. 7 (2009).

38. Turkelboom, F. et al. When we Cannot Have It All: Ecosystem Services Trade-Offs in the Context of Spatial Planning. Ecosystem Services. 29, 566-578 (2018).

39. Joa, B., Winkel, G. \& Primmer, E. The Unknown Known - a Review of Local Ecological Knowledge in Relation to Forest Biodiversity Conservation. Land Use Policy. 79, 520-530 (2018).

40. Baruch, B. M. The Road to Survival. Vital Speeches of the Day (1948).

41. Midgley, G. F. Ecology. Biodiversity and Ecosystem Function. Science. 335 (2012).

42. Mace, G. M., Norris, K. \& Fitter, A. H. Biodiversity and Ecosystem Services: A Multilayered Relationship. Trends Ecol. Evol. 27 (2011)

43. Randall, A. The Value of Biodiversity. Ambio. 2, 64-66 (1991)

44. García-Llorente, M. et al. What Can Conservation Strategies Learn From the Ecosystem Services Approach? Insights From Ecosystem Assessments in Two Spanish Protected Areas. Biodivers. Conserv. 27, 1575-1597 (2018).

45. Sultan, D. et al. Efficiency of Soil and Water Conservation Practices in Different Agro-Ecological Environments in the Upper Blue Nile Basin of Ethiopia. J. Arid Land. 10, 249-263 (2018).

46. Yang, B., Dong, C., Liang, T., Yu, F. \& Zhe, Z. Assessing the Importance of Water Conservation Function in Wuhan City Circle (In Chinese). Journal of Geo-information Science. 233-241 (2014).

47. Zhong-Wu, L., Qi, Z., Guang-Ming, Z., Hua, Z. \& Jing-Ling, Y. Soil and Water Erosion of Fragile Ecosystem in Red Soil Hilly Region based on GIS: A Case Study in Changsha City (In Chinese). Resources Science. 201-206 (2006).

48. Zhou, J. et al. Effects of Precipitation and Restoration Vegetation On Soil Erosion in a Semi-Arid Environment in the Loess Plateau, China. Catena. 137, 1-11 (2016).

49. Gathagu, J., Mourad, K. \& Sang, J. Effectiveness of Contour Farming and Filter Strips on Ecosystem Services. Water-Sui. 10, 1312 (2018).

50. Pimentel, D. et al. Environmental and Economic Costs of Soil Erosion and Conservation Benefits. Science. 267, 1117-1123 (1995).

51. Wei-Li, Z., Shu-Xia, W., Hong-Jie, J. \& Kolbe, H. Estimation of Agricultural Non-Point Source Pollution in China and the Alleviating Strategies (In Chinese). Scientia Agricultura Sinica. 1008-1017 (2004).

52. Guang-Ming, Y., Jian-Feng, Z. \& He-Ping, X. Numerical Simulation of Fractal Interface Effect of Mining-Caused Activation of Fault. Discrete Dyn. Nat. Soc. 7 (2002).

53. Zhang, J. et al. Bioavailability and Soil-To-Crop Transfer of Heavy Metals in Farmland Soils: A Case Study in the Pearl River Delta, South China. Environ. Pollut. 235, 710-719 (2018).

54. Guang, L. Influence and Strategy of Ground Setting on Buildings in Dezhou City. Journal of Qingdao Technological University. 26-29 (2010).

55. Lie-Rong, L., Jian-Jun, J. \& Wen, W. Geological Relics Resources and their Management in China (In Chinese), China Land Press, 2002).

56. Li-Wei, Z., Chun-Ku, Y., Zhi-Hai, J. \& Qian, Z. SignificanceI of Building Pingdingshan Gelogical Heritage Protection Area in Chaohu, Anhui, CHINA (In Chinese). Journal of Geological Hazards and Environment Preservation. 61-65 (2008).

57. Massoud, E. C., Purdy, A. J., Miro, M. E. \& Famiglietti, J. S. Projecting Groundwater Storage Changes in California'S Central Valley. Sci. Rep.-UK. 8 (2018). 


\section{Acknowledgements}

The Project was Supported by the Fundamental Research Funds for the Central Universities, China University of Geosciences (Wuhan) (No: CUGCJ1822). The authors thank Chen Wen of the Wuhan Geological Survey Center, who contributed over the years to this study and provide the data support. The author is grateful to Editor SangBing Tsai and the two reviewers for their work, their suggestions have greatly improved the quality of the article.

\section{Author contributions}

Gao Lin and Ma Chuanming wrote the main manuscript text and collected data, Gao Lin and Wang Qixin prepared Figs 1-14; Zhou Aiguo proposed amendments to this article.

\section{Competing interests}

The authors declare no competing interests.

\section{Additional information}

Correspondence and requests for materials should be addressed to C.M.

Reprints and permissions information is available at www.nature.com/reprints.

Publisher's note Springer Nature remains neutral with regard to jurisdictional claims in published maps and institutional affiliations.

Open Access This article is licensed under a Creative Commons Attribution 4.0 International License, which permits use, sharing, adaptation, distribution and reproduction in any medium or format, as long as you give appropriate credit to the original author(s) and the source, provide a link to the Creative Commons license, and indicate if changes were made. The images or other third party material in this article are included in the article's Creative Commons license, unless indicated otherwise in a credit line to the material. If material is not included in the article's Creative Commons license and your intended use is not permitted by statutory regulation or exceeds the permitted use, you will need to obtain permission directly from the copyright holder. To view a copy of this license, visit http://creativecommons.org/licenses/by/4.0/.

(c) The Author(s) 2019 